Milena Jakšić ${ }^{1}$

Miljan Leković ${ }^{2}$

Marina Milanović ${ }^{3}$
JEL: G12, G23

DOI: 10.5937/industrija43-6677

UDC:336.1.07(497.11)"2009/2012"

005.216 .1

Original Scientific Paper

\title{
Measuring the performance of mutual funds - a case study
}

\author{
Article history: \\ Received: 5 September 2014 \\ Sent for revision: 3 November 2014 \\ Received in revised form: 30 January 2015 \\ Accepted: 3 February 2015 \\ Available online: 1 April 2015
}

\begin{abstract}
In this paper we evaluate the performance of eight open-end mutual funds in the Republic of Serbia for the period 2009-2012, with the aim of testing the justification of active portfolio management of mutual funds, and determining the selection capability of Serbian portfolio managers. Riskweighted returns of mutual funds are compared with the risk-weighted return of the leading Belgrade Stock Exchange index, Belex15, whereas the following are used as performance measures: Sharpe ratio $\left(S_{i}\right)$, Treynor ratio $\left(T_{i}\right)$, and Jensen's or Alpha index $\left(\alpha_{i}\right)$. The results suggest that the portfolio of Serbian mutual funds has inferior performance compared to the market portfolio, which indicates the lack of selection capabilities of domestic portfolio managers.
\end{abstract}

Keywords: mutual funds, Sharpe ratio, Treynor ratio, Jensen's or Alpha index

\section{Merenje performansi otvorenih investicionih fondova - studija slučaja}

Apstrakt: $U$ radu se evaluiraju performanse osam otvorenih investicionih fondova u Republici Srbiji u periodu 2009-2012. godina sa ciljem ispitivanja opravdanosti aktivnog upravljanja investicionim fondovima $i$ utvrdivanja selekcione sposobnosti srpskih portfolio menadžera. Rizikom ponderisani prinosi investicionih fondova upoređuju se sa rizikom ponderisanim prinosom vodećeg indeksa Beogradske berze Belex15, a kao mere performansi koriste

\footnotetext{
${ }^{1}$ University of Kragujevac, Faculty of Economics, milenaj@kg.ac.rs

${ }^{2}$ University of Kragujevac, Faculty of Hotel Management and Tourism in Vrnjačka

Banja

${ }^{3}$ University of Kragujevac, Faculty of Economics 
Jakšić M. et al.: Measuring the performance of mutual funds - a case study

se: Sharpeov indeks $\left(S_{i}\right)$, Treynorov indeks $\left(T_{i}\right)$ i Jensenov ili alfa indeks $\left(\alpha_{i}\right)$. Rezultati istraživanja ukazuju da portfolio srpskih investicionih fondova ima inferiorne performanse $u$ odnosu na tržišni portfolio, što govori o nedostatku selekcione sposobnosti domaćih portfolio menadžera.

Ključne reči: investicioni fondovi, Sharpeov indeks, Treynorov indeks, Jensenov ili alfa indeks

\section{Introduction}

In the past few decades, economists have focused their attention on the analysis of the performance of mutual funds. The aim of the analysis is to determine whether the active portfolio management of mutual funds produces better results than those that would be realized by investing in assets that faithfully represent a leading stock index. The intent is to determine whether by active portfolio management of mutual funds managers achieve alpha returns, i.e. returns higher than the market return.

The choice between active and passive portfolio management of mutual funds is reduced to a debate about the validity of the efficient market hypothesis, according to which the prices of securities reflect all relevant information, preventing market participants from achieving extra return. Evidence that casts doubt on the hypothesis, such as the small firm effect, excessive volatility, the January effect etc., also speaks in favour of the selection of the strategy of active portfolio management of mutual funds. In other words, adopting the active strategy is based on the critique of the efficient market hypothesis. Critics of the efficient market hypothesis oppose the passive, and advocate active portfolio management of mutual funds.

In the past, investors were almost exclusively interested in investing in highyield funds, but the bankruptcy of many of them forced them to pay particular attention to another dimension of performance of funds, and that is the risk. Experience has shown that high-yield mutual funds often owe their results to the high level of risk and overall market trends, rather than the capability of portfolio managers.

Given the above, the research subject will focus on examining the justification of active portfolio management of mutual funds in Serbia, and determining the selection capability of Serbian portfolio managers. The aim of the paper is to analyse the performance of open-end mutual funds in Serbia for the period 2009-2012. The emphasis is on open-end mutual funds, given their dominance, not only in Serbia, but also around the world, according to the number and value of the assets managed. Therefore, this paper examines the risk-weighted returns of open-end mutual funds in Serbia, and each of them is 
Jakšić M. et al.: Measuring the performance of mutual funds - a case study

compared with risk-weighted return of the leading Belgrade Stock Exchange index, Belex15.

In accordance with the defined objective and the subject of research, the paper will test the following research hypotheses:

$H_{0}: \alpha=0$, The portfolio of the mutual fund has the same performance as the market portfolio,

$H_{1}: \alpha \neq 0$, The portfolio of the mutual fund has superior/inferior performance relative to the market portfolio.

\section{Literature review}

Measuring the performance of mutual funds has become an integral part of the financial literature in developed countries in early 1960s. The first empirical analysis of the performance of mutual funds was performed by Friend, Brown, Herma and Vickers in their paper "A Study of Mutual Funds", published in 1962 (Redman, Gullet, \& Manakyan, 2000, p. 76). A few years later, Jack Treynor (1965), William Sharpe (1966), and Michael Jensen (1968), independently from each other, introduced the standard performance measures that became known as Sharpe ratio, Treynor ratio, and Jensen's or alpha index. Starting from Jensen's study, conducted in 1968, most academic studies conclude that the net performance of mutual funds is inferior compared to market performance, i.e, most of the papers suggest that actively managed mutual funds are not able to outperform the market index returns. Jensen (1968) studied the performance of 115 mutual funds in the period 1945-1964, and found that their managers failed to achieve returns higher than those that were expected given the level of risk taken. Similar conclusions were drawn by Chang and Lewellen (1985), Bogle (1991), Droms and Walker (1994), Harlow and Brown (2006). However, in the late 1980s and early 1990s, conflicting studies appeared, such as those carried out by Ippolito (1989), pointing to the conclusion that mutual funds had enough private information to outweigh the costs incurred (Otten \& Bams, 2002, p. 76).

The financial literature particularly deals with the performance evaluation of European mutual funds, carried out by Otten and Bams (2002) on a sample of 506 funds from five countries: France (99 funds), Germany (57 funds), Italy (37 funds), the Netherlands (9 funds), and Great Britain (304 funds). The conclusion of their study is that the average European mutual fund is able to add, i.e. exceed the relevant market indices, which is shown by positive net alphas. Unfortunately, the obtained results lacked statistical significance, which was, if the truth be told, achieved by the addition of management fees, so that 
the mutal funds in the case of four out of five analysed countries had positive and statistically significant gross alphas. Similar results were obtained by Redman et al. (2000), who explored the performance of international mutual funds in the period 1985-1994. The conclusion of their work is that the funds in the observed period had positive but not statistically significant alpha indices, as well as that the performance of funds varied depending on the period of observation. Specifically, in the period 1985-1989, the analysed funds managed to achieve positive and statistically significant alpha indices, while in the period from 1990 to 1994 negative alpha indices without statistical significance were achieved.

On the other hand, the literature on the mutual funds and measuring their performance in less developed countries, such as Central and Eastern Europe, is relatively sparse, despite the fact that with the fall of socialism and the transition to market-oriented economic system these countries attracted considerable attention of investors. The issue of performance evaluation of open-end mutual funds in Central and Eastern Europe attracted the attention of researchers in early 2000s. Bialkowski and Otten (2011) explored the performance of mutual funds in Poland in the period 2000-2008 on a sample of 140 funds, and concluded that Polish mutual funds on average are unable to add value, i.e. outperform the relevant market indices, which is indicated by negative net alphas. The above-mentioned authors, however, acknowledge that the addition of management fees ensures positive and statistically significant alphas for domestic funds, i.e. negative alphas without statistical significance for international funds. These results suggest that domestic mutual funds in Poland are more successful than international funds, due to informational superiority of domestic over foreign investors, as well as that their managers have the selection capability, but that they charge excessively high fees.

Evaluation of the performance of Polish mutual funds in one year shorter period, 2000-2007, was carried out by Swinkels and Rzezniczak (2009) on a sample of 38 Polish mutual funds. By measuring the performance, these authors achieved positive alphas without statistical significance, which implies that mutual fund portfolio has the same performance as the market portfolio. In other words, Swinkels and Rzezniczak (2009) demonstrated neither the superiority nor the inferiority of mutual funds performance in relation to the market performance. Similar results were obtained by Markovic-Hribernik and Vek (2013), who analysed the performance of mutual funds in Slovenia with sectoral investment policy Energy, for the period from January 2005 to August 2009. Seven out of nine surveyed funds had positive alpha indices of low nominal value, but none of them had the required statistical significance, so that the authors could not confirm the selection superiority of mutual fund managers. 
The mutual fund performance in Slovenia was also measured by Jagric, Podobnik, Strasek, \& Jagric, (2007), but the results of their study were somewhat different. Specifically, the authors limited their study to the period from 1 July 2000 to 31 December 2003, including funds older than three years. All nine analysed funds achieved positive alpha ratio values, six of which were statistically significant. It implies that, according to the presented survey, the Slovenian mutual fund managers in the observed period managed to outperform the market by showing the remarkable selection capability. In addition to the above, there are the results obtained by Podobnik, Balen, Jagric, \& Kolanovic, (2007), who analysed the performance of Slovenian mutual funds on a sample of fourteen funds in the period from 31 December 1999 to 31 August 2006. All observed funds achieved positive alpha indices, with $50 \%$ of them being statistically significant. In the same paper, Podobnik et al. (2007) evaluated the performance of Croatian and Bosnian mutual funds. Out of fourteen observed mutual funds in Croatia in the period from 1 Januar 2004 to 31 December 2005, eleven funds achieved positive alpha indices, with only one result being statistically significant. In Bosnia, eight out of nine analysed funds in a three-year period from 1 April 2003 to 1 April 2006 had positive alpha indices, which indicates the potential selection superiority of their managers. However, as in the case of Croatia, only one alpha index had the required statistical significance. The above-mentioned authors' conclusion reflects the apparent dominance of Slovenian compared to Croatian and Bosnian mutual funds, in respect of the performance and the selection capability of their managers.

The researchers noted that the results of the performance evaluation of active management largely depend on the choice of benchmark, or the market index. Sajter (2011) resolved this issue in his work by opting for five relevant market indices for each investment fund, instead of choosing one market index, using the geographic exposure of fund assets as the basic selection criterion. According to Sajter, a larger number of benchmarks can only strengthen, not weaken, the results. The importance of each market index as a benchmark is approximately proportional to the share of fund assets invested in assets that faithfully represent the given index (Sajter, 2011, p. 256). In his paper, Sajter (2011) specifically examines the performance of the five largest Croatian openend stock mutual funds, by comparing their risk-weighted returns to riskweighted returns of the relevant market indices. The research covered the period from the establishment of funds to August 2010. It was concluded that the returns of funds could not outperform market returns, as evidenced by the negative alpha indices. The author admits that the positive alphas were generated in the pre-crisis period, but their value was insufficient to cover the management fees, and unsustainable in the future. 
Given the above, it can be seen that most of the papers show that after taking into account the costs, average mutual fund fails to outperform the appropriate market index.

\section{Materials and Methods}

The paper uses the Belgrade Stock Exchange Index, Belex15, as the benchmark, while the average annual rate of return on treasury bills of the National Bank of Serbia has been taken as the risk-free rate of return. Data on return of open-end mutual funds in the Republic of Serbia, as well as data on average annual return on treasury bills of the National Bank of Serbia, have been taken from the annual reports on operations of the Securities Commission, while data on the movement of the index Belex15 have been taken from the website of the Belgrade Stock Exchange. It is important to note that the management fees have not been taken into account in the study, since mutual funds publish their returns on a gross basis, so that the selection capability of portfolio managers of mutual funds will be measured by gross Jensen's alpha.

The starting point of the research is the Capital Asset Pricing Model (CAPM), which Jack L. Treynor (1961-1962), John Lintner (1965a-1965b), William F. Sharpe (1964), and John Mossin (1966) developed, independently from each other, based on the previous work of Harry Markowitz. According to the CAPM, the mutual fund return is a linear function of systemic risk $(B)$ and the selection capability $(\alpha)$, i.e. it equals the sum of risk-free return, market premium, and selection capability of managers (Markovic-Hribernik \& Vek, 2013, p. 132).

$R_{i, t}=\alpha_{i}+R_{f, t}+\beta_{i}\left(R_{m, t}-R_{f, t}\right)+\varepsilon_{i, t}$

where:

$R_{i, t}$ - the average return of mutual fund $i$ in time $t$,

$\alpha_{i}$ - Jensen's or alpha index,

$R_{f, t}$ - the average risk-free return in time $t$,

$\beta_{i}$ - beta coefficient of mutual fund portfolio $i$,

$R_{m, t}$ - the average market return in time $t$,

$\varepsilon_{i, t}-$ stochastic return of fund $i$ in time $t$ (residual return).

The CAMP requires that the expected returns of open-end mutual funds are linearly dependent on their covariance with the market (Swinkels \& 
Rzezniczak, 2009). The basic performance measures are derived from CAMP: Sharpe ratio $\left(S_{i}\right)$, Treynor ratio $\left(T_{i}\right)$ and Jensen's or alpha index $\left(\alpha_{i}\right)$. The higher these indices are, the more efficient mutual funds, i.e. their portfolios are, meaning that they have better performance.

Sharpe ratio $\left(S_{i}\right)$ is calculated by dividing the risk premium, i.e. the excess return, by the standard return deviation as the total risk measure $\left(\sigma_{i}\right)$.

$S_{i}=\frac{R_{i}-R_{f}}{\sigma_{i}}$

This index summarizes the benefits and costs of investing - the average return and standard deviation, into one performance measure, and shows whether the fund returns are the result of smart investment decisions or immoderate risk. The advantage of using the Sharpe index in the course of fund performance evaluation is reflected in the fact that during its computation, there is no need to determine the benchmark as a market proxy, so that the choice of benchmark does not affect the ranking of funds by this index (Miročević, 2006, p. 28-29). On the other hand, the major drawback of Sharpe ratio lies in the fact that it is a reliable performance indicator of only non-diversified or poorly diversified portfolio.

On the other hand, Treynor ratio $\left(T_{i}\right)$ is similar to Sharpe ratio $\left(S_{i}\right)$, except that instead of the standard deviation as a measure of the volatility of fund returns, their mean values are obtained by using beta coefficient (ß).

$T_{i}=\frac{R_{i}-R_{f}}{\beta_{i}}$

Therefore, Treynor ratio is calculated by dividing the rate of return above the risk-free rate of return by a beta coefficient as a measure of systemic risk. Beta coefficient measures the market exposure of the mutual fund, namely, the sensitivity of fund return to the market index (Swinkels \& Rzezniczak, 2009), and can be represented by the following formula:

$\beta_{i}=\frac{\sigma_{i} \times \rho_{i, t}}{\sigma_{m}}$

where:

$\beta_{i}$ - beta coefficient of mutual fund portfolio $i$,

$\sigma_{i}$ - standard deviation of mutual fund $i$,

$\sigma_{m}$ - standard deviation of the market index, 
Jakšić M. et al.: Measuring the performance of mutual funds - a case study

$\rho_{i, m}-$ correlation coefficient of mutual fund and the market.

The positive beta coefficient means that mutual fund return is moving in the direction of movement of the market return, while the negative beta coefficient indicates the contrary. The value of beta coefficient between 0 and 1 indicates the movement weaker than the market movements, while the beta coefficient greater than one points to stronger fluctuations than those in the market. In calculating the beta coefficient, among other things, the correlation coefficient is used, as a measure of the degree to which two sets of numbers tend to move together up or down. The value of the correlation coefficient ranges from -1 (perfect negative correlation) to +1 (perfect positive correlation), and is determined as follows:

$\rho_{i, m}=\frac{\operatorname{Cov}_{i, t}}{\sigma_{i} \times \sigma_{m}}$

where:

$\operatorname{Cov}_{i, t}-$ the covariance between mutual fund return and the market return.

Based on the above, it can be concluded that the higher Sharpe ratio means higher excess return per unit of total risk, as measured by standard deviation, while the higher Treynor ratio means higher excess return per unit of systemic risk, as measured by the beta coefficient. If the portfolio is well diversified, both performance measures, Sharpe ratio and Treynor ratio, will give the same results, because then the total risk equals systemic risk, while the Treynor ratio higher than the Sharpe ratio indicates the insufficient diversification and the presence of non-systemic risk.

However, although they stand for useful instruments for measuring the performance of mutual funds, neither Sharpe, nor Treynor ratio show the extra return achieved through active portfolio management, which is why Jensen (1968) derived alpha index $\left(\alpha_{i}\right)$ from the CAMP regression equation, which eliminates the above deficiencies.

$\alpha_{i}=R_{i, t}-\left[R_{f, t}+\beta_{i}\left(R_{m, t}-R_{f, t}\right)\right]$

Alpha index stands for the difference between the actual fund return and the expected return at a given level of risk. If the actual fund return is higher than the expected return, alpha index is positive, the fund performance superior, and the mutual fund manager capable of achieving extra return and winning the market, thus showing the selection capability. However, if the realised rate of return is lower than expected on the basis of portfolio risk, the alpha index is negative, the fund performance inferior, and the mutual fund manager lacks the necessary selection capability. Finally, the equality of actual and expected 
return indicates the average mutual fund performance, which is considered to be a market, and the alpha index in this case is equal to zero. Another important fact that should be added is that Jensen's alpha must be statistically significant in order to even be taken into consideration. If alpha is not statistically significant, mutual fund portfolio has the same performance as the market portfolio. The process of determining the statistical significance ( $t$ statistic) is as follows: 1) first, appropriate hypotheses are formulated as $\mathrm{Ho}$ : $\alpha=0$ and $\left.H_{1}: \alpha \neq 0 ; 2\right)$ then the standard error of alpha is calculated $\left(S_{e}(\alpha)\right)$ (Teall, 1999, p. 29):

$$
S_{e}(\alpha)=\sqrt{\frac{\frac{\sum \varepsilon_{i}^{2} \times \sum x_{i}^{2}}{n-2}}{n \times \sum\left(x_{i}-\bar{x}\right)^{2}}}
$$

where: $\varepsilon_{i}=\left(R_{i}-R_{f}\right)-\left(\alpha+\beta_{i}\left(R_{m}-R_{f}\right)\right), x_{i}=R_{m}-R_{f}$;

3) finally, the alpha index is divided by the calculated standard error, and the resulting value compared to the corresponding critical value:

$t(\alpha)=\frac{\alpha}{S_{e}(\alpha)}$

The conclusion is that Jensen's alpha, derived from the regression equation, measures the mutual fund managers' selection capability of securities, pointing to their inferiority $(\alpha<0)$ or superiority $(\alpha>0)$. The inferior manager has Jensen's alpha which is significantly negative, while the superior manager has a positive and statistically significant value of alpha index (Jagric et al., 2007, p. 237).

\section{Results and discussion}

The analysed four-year period from 2009 to 2012 is characterised by a negative impact of the current global economic crisis, which has not bypassed the emerging Serbian sector of mutual funds (Table 1). The first mutual funds in Serbia appeared just a year before the onset of the global financial crisis, specifically in 2007.

The positive average annual return for the period 2009-2012 was achieved only by the mutual fund Ilirika Euro, which also managed to significantly outperform the average annual return of the leading Belgrade Stock Exchange Index, Belex15. The mutual fund Triumph Balance slightly outperformed the market return, implying that this fund achieved less negative average annual return during the analysed period. Returns of all other mutual funds were, on 
average, more negative than the market return. However, the comparison of the average four-year return of open-end mutual funds in Serbia with an average four-year market return does not say much about the justification of active management of mutual funds, which is the task of the research, because it does not take into account the risk as the second important dimension of fund performance. Therefore, it is necessary to compare the risk-weighted returns of investment funds with risk-weighted return of the leading Belgrade Stock Exchange Index, Belex15. In this way, it is possible to get a better picture of the efficiency of mutual funds and the selection capability of Serbian portfolio managers.

Table 1. The average annual return (Ri), the excess return (Ri-Rf), and Sharpe ratio $\left(S_{i}\right)$ of mutual funds in Serbia in the period 2009-2012

\begin{tabular}{|c|c|c|c|c|c|c|c|c|}
\hline \multirow{2}{*}{$\begin{array}{l}\text { Name of } \\
\text { the fund }\end{array}$} & \multicolumn{4}{|c|}{ Annual return } & \multirow[b]{2}{*}{$\mathrm{Ri}$} & \multirow[b]{2}{*}{ Ri-Rf } & \multirow{2}{*}{$\begin{array}{c}\text { St } \\
\text { Dev }\end{array}$} & \multirow{2}{*}{$\begin{array}{c}\text { Sharpe } \\
\text { ratio }\end{array}$} \\
\hline & 2009 & 2010 & 2011 & 2012 & & & & \\
\hline $\begin{array}{l}\text { Fima } \\
\text { ProActive }\end{array}$ & -0.287 & -0.019 & -0.049 & -0.051 & -0.102 & -0.220 & 0.125 & -1.763 \\
\hline $\begin{array}{l}\text { llirika } \\
\text { Dynamic }\end{array}$ & -0.263 & -0.133 & -0.103 & -0.162 & -0.165 & -0.283 & 0.069 & -4.077 \\
\hline $\begin{array}{l}\text { llirika } \\
\text { Euro }\end{array}$ & 0.026 & -0.021 & 109 & -0.083 & 0.008 & 110 & 0.081 & -1.362 \\
\hline $\begin{array}{l}\text { Ilirika } \\
\text { Global }\end{array}$ & -0.158 & 0.002 & -0.202 & -0.131 & -0.122 & -0.240 & 0.088 & -2.735 \\
\hline $\begin{array}{l}\text { llirika } \\
\text { Plus }\end{array}$ & -0.217 & -0.056 & -0.085 & -0.179 & -0.134 & -0.252 & 0.076 & -3.312 \\
\hline $\begin{array}{l}\text { KomBank } \\
\text { InFond }\end{array}$ & -0.06 & -0.078 & -0.212 & -0.021 & -0.093 & -0.211 & 0.083 & -2 \\
\hline Triumph & 0.017 & -0.041 & 0.254 & -0.434 & -0.051 & -0.169 & 0.285 & -0.592 \\
\hline $\begin{array}{l}\text { Triumph } \\
\text { Balance }\end{array}$ & 2 & -0 & -0.101 & -0 & -0.006 & 24 & 084 & 37 \\
\hline Belex15 & .174 & -0.018 & 234 & 0.050 & -0.007 & -0.125 & 0.171 & -0.730 \\
\hline
\end{tabular}

Note: The average annual rate of return on treasury bills of the NBS for the period 2009-2012 was $11.8 \%(\mathrm{Rf}=0.118)$.

Source: Authors' calculation

Sharpe ratio, as the first introduced performance measure, which summarizes both the benefits and costs of investing, i.e. both return and risk, usually has a value between 0.5 and 3 . According to a "rule of thumb", if the annual Sharpe ratio is higher than 1.0 , the fund has a pretty good year, while extraordinary funds have Sharpe ratio greater than 2.0 (Jagric et al., 2007, p. 239). In the conducted research, Sharpe ratio is negative for all tested open-end mutual funds in Serbia, which is to be expected in times of severe crisis, when the 
goal of active management is not to get more, but to lose less, or to achieve less negative returns. Interpretation of negative Sharpe ratio is the same as the interpretation of positive Sharpe ratio. In other words, the rule that the higher the ratio, the better the fund performance, is still valid (Sajter, 2011, p. 259). The largest Sharpe ratio in the analysed period was recorded in the case of open-end mutual fund Triumph $\left(S_{i}=-0.592\right)$, which makes it the fund with the least negative excess return per unit of total risk, whereas the mutual fund llirika Dynamic recorded the lowest Sharpe ratio $\left(S_{i}=-4.077\right)$.

Much more valuable information than the absolute value of the Sharpe ratio is that this index for all funds, except for the mutual fund Triumph, is lower than the Sharpe ratio for the benchmark Belex15 which is -0.730 . Therefore, according to Sharpe ratio, seven out of eight analysed funds have inferior performance compared to the benchmark. However, given that the Sharpe ratio $\left(S_{i}\right)$ is a reliable performance indicator of only non-diversified or poorly diversified portfolio, the indicators such as Treynor ratio $\left(T_{i}\right)$ and Jensen's or alpha index $\left(\alpha_{i}\right)$ must be calculated in the course of the research (Table 2).

Table 2. Performance of mutual funds in Serbia for the period 2009-2012

\begin{tabular}{|l|c|c|c|c|c|}
\hline Name of the fund & $\begin{array}{c}\text { Sharpe } \\
\text { ratio }\end{array}$ & $\begin{array}{c}\beta \\
\text { coefficient }\end{array}$ & $\begin{array}{c}\text { Treynor } \\
\text { ratio }\end{array}$ & $\begin{array}{c}\text { Jensen's } \\
\text { alpha }\end{array}$ & $\begin{array}{c}\mathrm{t}- \\
\text { statistic }\end{array}$ \\
\hline Fima ProActive & -1.763 & -0.496 & 0.442 & -0.282 & -3.860 \\
\hline llirika Dynamic & -4.077 & -0.365 & 0.777 & $-0.329^{\star}$ & -13.450 \\
\hline llirika Euro & -1.362 & -0.279 & 0.395 & -0.145 & -2.774 \\
\hline llirika Global & -2.735 & 0.111 & -2.163 & -0.226 & -3.295 \\
\hline llirika Plus & -3.312 & -0.337 & 0.749 & $-0.294^{\star}$ & -7.387 \\
\hline KomBank InFond & -2.540 & 0.420 & -0.501 & $-0.158^{\star}$ & -4.779 \\
\hline Triumph & -0.592 & -0.897 & 0.188 & -0.281 & -1.458 \\
\hline Triumph Balance & -1.487 & 0.458 & -0.271 & -0.067 & -2.887 \\
\hline Belex15 & -0.730 & 1.000 & -0.125 & 0.000 & \\
\hline
\end{tabular}

$\left.{ }^{*}\right)$ denotes statistical significance at the level of $5 \%$.

Source: Authors' calculation

Treynor ratio $\left(T_{i}\right)$ is calculated by dividing the excess return with beta coefficient, as a measure of market exposure of the mutual fund. Beta coefficient was negative for most of the analysed funds in this period, which indicates that mutual fund returns generally moved in the direction opposite to the direction of movement of the market return. The funds Ilirika Global, 
Jakšić M. et al.: Measuring the performance of mutual funds - a case study

KomBank InFond, and Triumph Balance were the only ones to have a positive beta coefficient.

The calculated Treynor ratio is for most funds positive and greater than Treynor ratio for the benchmark Belex15, which is equal to the risk premium and amounts to $T_{i}=-0.125$. The fund with the highest Treynor ratio, Ilirika Dynamic $\left(T_{i}=0.777\right)$, is the fund with the highest excess return per unit of systemic risk, while the highest negative excess return per unit of systemic risk was recorded in the case of mutual fund llirika Global $\left(T_{i}=-2.163\right)$.

Therefore, Sharpe ratio points to inferior, whereas Treynor ratio points to superior performance of Serbian mutual funds. What is more, Treynor ratio is for each mutual fund higher than the Sharpe ratio, which can be explained by the presence of high non-systemic risk caused by insufficient portfolio diversification. Also, it should be noted that the possible ranking of funds by Sharpe and Treynor ratios would be different, which confirms the conclusion that the portfolios of mutual funds in Serbia are not well diversified.

Regardless of their undeniable usefulness, Sharpe and Treynor ratios still do not show whether the managers were able to outperform the market through active management, i.e the Belgrade Stock Exchange Index, Belex15. The answer to this question is provided by Jensen's alpha, which must be statistically significant to be taken into account. In the conducted research, alpha indices were negative for all tested open-end mutual funds in Serbia for the period 2009-2012, while the negative and statistically significant alpha index value was recorded by the funds Ilirika Dynamic, Ilirika Plus, and KomBank InFond. As the result of these funds is statistically significant, the null hypothesis is rejected, and the research hypothesis $H_{1}$ is accepted. Therefore, about $40 \%$ of the analysed mutual funds have inferior performance compared to the market portfolio, while for the remaining funds, the null hypothesis $\left(H_{0}\right)$, based on which mutual fund portfolio has the same performance as the market portfolio, cannot be rejected regardless of the negative alpha index value.

Research has shown that mutual funds in Serbia in the analysed four-year period lost more value than the market index, which means that the active management contributed to the results which were worse than expected. Inferiority of fund performance would be even higher if the management fees were included in the analysis, and the net Jensen's alpha was calculated, or, if the analysis included transaction costs. Serbian mutual fund managers simply lack the selection capability, i.e. the needed skills of choice of action. 
Jakšić M. et al.: Measuring the performance of mutual funds - a case study

\section{Conclusions}

Evaluation of the performance of mutual funds has become an integral part of the world's financial literature in the early 1960s, when it started attracting considerable attention of economists. However, in the countries of Central and Eastern Europe, including Serbia, this issue has become popular forty years later, as evidenced by the scant number of papers on the above-mentioned subject.

Serbia significantly lags behind highly developed countries, when the development of mutual fund sector is taken into consideration. The emergence of mutual funds in Serbia just before the onset of the global economic crisis has slowed down their development, whereas the issue of performance evaluation of Serbian mutual funds has not been handled yet. Using existing international research and conducting personal research enabled the supplementing of literature in this area of research, and helped in making the first step in the study of domestic literature. The motive for the conducted research lies exactly in the intention to at least partially alleviate the chronic shortage of domestic literature on measuring performance of mutual funds. So, from the theoretical point of view, the work is expected to contribute to the enrichment of the literature in this area in Serbia, while in terms of application, potential contribution of the conducted researchis reflected in the application of the presented methods and models in assessing the performance of the portfolio by potential investors on the Serbian financial market.The research results can be useful especially for large institutional investors in Serbia.

This paper has evaluated the performance of eight open-end mutual funds in Serbia for the period 2009-2012, by applying Sharpe ratio $\left(S_{i}\right)$, Treynor ratio $\left(T_{i}\right)$, and Jensen's or Alpha index $\left(\alpha_{i}\right)$. According to Sharpe ratio, seven of eight analysed funds have had inferior performance compared to the benchmark. Treynor ratio has been for most funds positive and greater than Treynor ratio for benchmark Belex15, while the alpha indices have been negative for all tested open-end mutual funds in Serbia. Statistically significant negative value of alpha index has been observed in the case of about $40 \%$ of the analysed funds. The research results clearly indicate that the portfolio of Serbian mutual funds has inferior performance compared to the market portfolio, which means that the task of active management is not realized because the active management has produced worse results than expected. The causes of poor results should be sought in insufficient experience and poor selection capability of Serbian portfolio managers, as well as in the fact that, in times of crisis, correlation coefficients converge to one, thus eliminating the benefits of diversification. The obtained results are consistent with the 
conclusions drawn by Jensen (1968), Chang and Lewellen (1985), Harlow and Brown (2006), Sajter (2011) and others.

The conducted research of performance of open-end mutual funds involves certain constraints, the most important being related to the time dimension of data. Due to the inability to collect enough long time series, empirical research has been conducted on the basis of a relatively small number of annual data. Therefore, the conclusion of the analysis should be taken with caution, since the available time series are not long enough to allow a high degree of reliability of the obtained scores. The results of this analysis can be characterised as preliminary research, aimed at presenting methodological aspects of future work with a larger database. Future research will focus on increasing the number of data through deaggregation, and collecting data for a period of less than one year.

\section{References}

Bialkowski, J., \& Otten, R. (2011). Emerging market mutual fund performance: evidence for Poland. The North American Journal of Economics and Finance, 22(2), 118-130. Retrieved from http://najef.utsa.edu/index.html

Bogle, J. (1991). Investing in the 1990s. The Journal of Portfolio Management, 17(3), 514. Retrieved from http://www.iijournals.com/toc/jpm/current

Chang, E. C., \& Lewellen, W. C. (1985). An arbitrage pricing approach to evaluating mutual fund performance. Journal of Financial Research, 8, 15-30. Retrieved from http://www.depts.ttu.edu/rawlsbusiness/about/finance/jfr/

Droms, W. G., \& Walker, D. A. (1994). Investment performance of international mutual funds. Journal of Financial Research, 17, 1-14. Retrieved fromhttp://www.depts.ttu.edu/rawlsbusiness/about/finance/jfr/

Harlow, W., \& Brown, K. (2006). The right answer to the wrong question: identifying superior active portfolio management. Journal of Investment Management, 4(4), 15-40. Retrieved from https://www.joim.com/index0.asp

Ippolito, R., (1989). Efficiency with costly information: a study of mutual fund performance. Quarterly Journal of Economics, 104, 1-23. Retrieved from http://qje.oxfordjournals.org/

Jagric, T., Podobnik, B., Strasek, S., \& Jagric, V. (2007). Risk-adjusted performance of mutual funds: some tests. South-Eastern Europe Journal of Economics, 2, 233-244. Retrieved from http://www.asecu.gr/Seeje/

Jensen, M. C. (1968). The performance of mutual funds in the period 1945-1964. The Journal of Finance, 23, 389-416. Retrieved from http://onlinelibrary.wiley.com/journal/10.1111/(ISSN)1540-6261

Linter, J. (1965a). The Valuation of Risk Assets and the Selection of Risky Investments in Stock Portfolios and Capital Budgets, The Review of Economics and Statistics, 47(1), 13-37. $\quad$ Retrieved from https://thedata.harvard.edu/dvn/dv/restat 
Jakšić M. et al.: Measuring the performance of mutual funds - a case study

Linter, J. (1965b). Securities Prices, Risk, and Maximal Gains from Diversification, The Journal of Finance, 20(4), 587-615. Retrieved from http://onlinelibrary.wiley.com/journal/10.1111/\%28ISSN\%291540-6261

Markovic-Hribernik, T., \& Vek, U. (2013). Do mutual fund performance and the abilities of fund managers in Slovenia deviate from those in developed markets? Romanian Economic and Business Review, 8(1), 130-139. Retrieved from http://www.rebe.rau.ro/about.html

Miročević, M. (2006). Portfolio performance measures: empirical analysis. Ekonomska misao, 39(1-2), 19-36. Retrieved from http://scindeks.ceon.rs/journalDetails.aspx?issn=0013-323X

Mossin, J. (1966). Equilibrium in a Capital Asset Market, Econometrica, 34(4), 768-783. Retrieved from http://onlinelibrary.wiley.com/journal/10.1111/(ISSN)1468-0262

Otten, R., \& Bams, D. (2002). European mutual fund performance. European Financial Management, 8(1), 75-101. Retrieved from http://onlinelibrary.wiley.com/journal/10.1111/(ISSN)1468-036X

Podobnik, B., Balen, V., Jagric, T., \& Kolanovic, M. (2007). Croatian and Slovenian mutual funds and Bosnian investments funds. Czech Journal of Economics and Finance, 57(3-4), 159-177. Retrieved from http://journal.fsv.cuni.czl

Redman, L. A., Gullet, N. S., \& Manakyan, H. (2000). The performance of global and international mutual funds. Journal of Financial and Strategic Decisions, 13(1), 75-85. Retrieved from http://www.studyfinance.com/jfsd/

Sajter, D. (2011). Can Croatian fund managers create alpha returns? Performance of some mutual funds in Croatia. Ekonomski pregled, 62(5-6), 248-266. Retrieved from http://www.hde.hr/pregled.aspx

Securities Commission of the Republic of Serbia. (2013). Report on operations of the Securities Commission of the Republic of Serbia and on trends in the capital market in the period: January - December 2012. Retrieved from http://www.sec.gov.rs/

Sharpe, W. F. (1966). Mutual fund performance. The Journal of Business, 39, 119-138. Retrieved from http://www.jstor.org/page/journal/jbusiness/about.html

Sharpe, F. W. (1964). Capital Asset Prices: A Theory of Market Equilibrium Under Conditions of Risk, The Journal of Finance, 19(3), 425-442. Retrieved from http://onlinelibrary.wiley.com/journal/10.1111/\%28ISSN\%291540-6261

Swinkels, L., \& Rzezniczak, P. (2009). Performance evaluation of Polish mutual fund managers. International Journal of Emerging Markets, 4, 26-42. Retrieved from http://www.emeraldinsight.com/journal/ijoem

Teall, L. J. (1999). Financial market analytics. Quorum Books, Westport, Connecticut: London.

Treynor, J. L. (1965). How to rate management of investment funds. Harvard Business Review, 43, 63-73. Retrieved from http://hbr.org/magazine

Treynor, J. L. (1962). Toward a Theory of Market Value of Risky Assets, Unpublished manuscript.

Treynor, J. L. (1961). Market Value, Time, and Risk, Unpublished manuscript. 